\title{
Ehdotus ihmistä suhteellistavaksi sanastoksi
}

Kaisa Kortekallio, Mariia Niskavaara, Hannah

Ouramo, Juha Raipola, Tarja Salmela, Ate Tervonen ja Sanna Karkulehto 
arvitsemme käsitteitä määritelläksemme ne yhteiset alueet, T joihin tutkimuksemme kohdistuu. Jos haluamme ajatella uudella tavalla, joudumme ajattelemaan myös käsitteemme uusiksi. Kuten Tuija Pulkkinen (2003, 216-217) muistuttaa, käsitteet eivät muutu yksinkertaisesti muuttamalla niiden kielellisiä ilmauksia. Toisaalta muutos ei myöskään tapahdu ilman sanoja - ja joskus ajattelussa on läsnä myös "käsitteitä, jotka ikään kuin etsivät ilmaisuaan".

Tässä sanastoehdotuksessa käsittelemme teoriasuuntausta, joka tunnetaan "posthumanistisena". Posthumanistinen ajattelu pyrkii käsitteelliseen uudistamiseen, jotta tunnistaisimme paremmin ne suhteellisuudet, joiden varassa ja lomassa ihmisten elämä ja merkitykset muotoutuvat - ja ne historiat, joissa ihminen on muotoutunut erilliseksi (ks. esim. Lummaa \& Rojola 2014; Braidotti 2019; Koistinen \& Karkulehto 2020). "Ehdotus ihmistä suhteellistavaksi sanastoksi" suhteellistaa juuri tätä käsitteellistä, kartesiolaisen humanismin ihmistä.

Käytämme posthumanismi-termiä paremman puutteessa. Termi on vakiintunut, se osoittaa kohti todellista ilmiötä ja sillä on selvä kommunikatiivinen merkitys. Kuitenkin se on hankala. Esimerkiksi feministiset ja post- tai dekolonialistiset ajattelijat ovat toistuvasti muistuttaneet, että posthumanismia vaivaa sama ajallisen rakenteen oletus kuin muitakin post-alkuisia suuntauksia, eikä se siten välitä ymmärrystä siitä, että länsimaiseen humanistiseen ajatteluun sitoutumatonta ajattelua on aina ollut olemassa (ks. esim. Jackson 2013; Viveiros de Castro 2019; Haapoja 2020). Samalla posthumanismi sisältää myös "ihmisen ylittämisen" merkityksen ja voittamattomat posthuman-hahmot, jotka kuvittavat populaaria posthumanismia (eli transhumanismia) (vrt. Raipola 2014). Vaikka kriittistä posthumanismia edustavassa työssämme tarkoituksena ei ole ylittää ihmisen inhimillisyyttä (rajallisuuden ja haavoittuvuuden merkityksessä), ylittämisen sävyt kulkevat termissä mukana.

Posthumanismin terminologinen hankaluus kietoutuu tutkimuksen perinteiden hankaluuteen. Tutkijoina olemme pääsemättömissä humanistisesta perinteestä: posthumanismi toimii aina humanismin sisällä, ei jälkeen. Donna Haraway (1997) kutsuu tällaista dynamiikkaa materiaalis-semioottiseksi: käsitteellinen ajattelumme on kehkeytynyt tietyissä historiallisissa konteksteissa tiettyjen materiaalisten ehtojen (tässä: eurooppalaisia perinteitä toistavien instituutioiden ja indoeurooppalaisten kielten) mahdollistamana, ja niillä on erilaisia konkreettisia seurauksia (tässä: tutkimusperinteitä, joissa ihmistä tarkastellaan erillisenä muista lajeista ja materiaalisista järjestelmistä). Humanistisen perinteen kritiikeistä on noussut myös uusia institutionaalisia rakenteita, joilla pyritään ei-ihmiskeskeiseen materiaalis-semioottiseen järjestäytymiseen: esimerkiksi humanistinen tai kulttuurinen eläintutkimus (human-animal studies) ja ihmistieteellinen ympäristötutkimus tai ympäristöhumanismi (environmental humanities). Näiden tutkimusalojen nimet eivät käänny suomen kieleen suoraan, vaan esimerkiksi "humanistisessa eläintutkimuksessa" jää näkymättömiin inhimillisten ja muiden eläinten välille hahmotettu vastavuo- 
roisuus ja vuorovaikutteisuus. Mahdottomalta käännettävältä vaikuttaa myös posthumanities (ks. esim. Braidotti 2013; 2019). Vaan onpa Harawayn (2016) humusities saanut suomenkielisen, myös "humuksesta" ammentavan vastineen, humismin - humanismi rapautuu tavu kerrallaan (Salminen \& Vadén 2018, 13).

Monikieliset tutkijat kääntävät termejä arkisena käytäntönä, monenlaisissa konteksteissa ja tekstilajeissa. Tieteellistä artikkelia kirjoittaessa sopivilta ja mielekkäiltä tuntuvat monimutkaisetkin termit, kuten tois-luonnollinen tai diffraktiivinen, mutta selittäessämme tutkimusaiheitamme ystäville tai kuvatessamme esimerkiksi suhteisuuttamme eläinkumppaneihimme puhekieleen asettuu merkityksiltään sumeita lotokoita, humaaneja ja hoomaneita. Tässä sanastoehdotuksessa olemme halunneet yhtäältä seurata käsitteellisen ajattelun muotoutumista erilaisten kontekstien paineissa, toisaalta pysähtyä tarkastelemaan tiettyjä, työskentelyssämme tärkeitä käsitteitä. Olemme pysähtyneet silloin, kun käsitettä kääntäessä tai käyttäessä tapahtuu jotain kiinnostavaa: englanninkielinen termi ei käänny yksiselitteisesti suomenkieliseksi termiksi; jotain käsitteessä muuttuu; tai ehkä muuttuukin se kokemuskenttä, jonka käsite avaa. Näin kiinnitämme huomion tiettyihin tilanteisiin, joissa ihmisen erityisasemaa haastava ajattelu kehkeytyy.

Näitä tilanteita avataksemme olemme keskittyneet vain yhdeksään termiin ja valikoituihin ajattelijoihin, joista kirjoitamme laveammin kuin tieto-, oppija tutkimuskirjallisuuden sanastoissa yleensä on tapana. Liikumme erityisesti englannin ja suomen kielen välillä. Emme tarkoita näitä rajauksia kattaviksi tai viimeistellyiksi - jäähän niiden ulkopuolelle paljon olennaisia termejä, keskustelijoita ja ajattelijoita. Pikemminkin toivomme, että tämä sanastoehdotus osallistuu laajempaan keskusteluun. Kannustamme tunnustelevaan uudelleenkirjoittamiseen, uudelleenpuhumiseenkin, ja (toisin)toistuvaan kyselemiseen, joka nousee tieteen instituutioiden sijaan ja ohella myös sanojen tunnuista ja ihmistä laajemmista kokemuksellisista kytköksistä.

elämä, epä/eläminen, elo

Kulttuurinen käsitys elämästä palaa helposti olemus- ja olentoajatteluun yhtäältä elävän yksilön rajattuun aikaan syntymän ja kuoleman välillä, toisaalta vaikkapa genetiikan tietoyksiköihin, joiden avulla biologista elämää voidaan kontrolloida ja optimoida. Elämän käsite on usein myös ihmiskeskeinen, jopa biografinen - elämä on se, mitä voidaan elämäkerrassa kertoa. Biopoliittiset kritiikit tarkastelevat tästä käsityksestä juontuvia vallankäytön tapoja (esim. Mbembe 2003; Agamben 1998). Elämän rajoja haastaa myös ei-biologinen elämä, kuten simuloivat ohjelmat ja algoritmit, jotka kehittyvät evolutiivisella logiikalla.

Biofilosofiassa elämä käsitetään "orgaanisen rajat ylittävänä aineellisena voimana, intensiteettinä, dynamismin muotona, kekseliäisyytenä, luovuutena 
sekä toisaalta tuhon ja toimettomuuden mahdollisuutena" (Radomska \& Åsberg 2020, 39; ks. myös Thacker 2015). Marietta Radomskan lisä tähän keskusteluun on epä/eläminen (non/living): "Gerundimuotoinen verbi korostaa sekä orgaanista että epäorgaanista materiaalista prosessuaalisuutta ja dynamiikkaa, ja kauttaviiva viittaa elävän ja elottoman yhteenkietoutumiseen" (Radomska \& Åsberg 2020, 42). ${ }^{2}$

Jälkifossiilista ajattelua edustavat Antti Salminen ja Tere Vadén (2018) puolestaan ehdottavat olemuksellisen elämän vastapainoksi eloa. Elo on tuttu termin aloittavana määreenä - elonkehä, elonkirjo - mutta itsenäisenä ja perusmuodossaan sitä näkee arkikielessä harvoin. Suomen kielessä "ollaan elossa", vailla tarvetta subjekti- tai objektipositioille. Salmisen ja Vadénin (2018, 21) mukaan kaikki elossa oleva on epämääräistä ja kaikki yksilöitävissä olevat elävät "ovat elossa vain toisten elollisten kanssa, niiden varassa, yhteydessä". Vaikka "[e]lämäkerrallinen elämä sulaa elon mereen", elo ei ole yksittäisten elämien, eliöiden tai lajien summa (Salminen \& Vadén 2018, 17). Elon ilmiön epämääräisyyttä ja monikäsitteisyyttä Salminen ja Vadén perustelevat sekä kielellisesti että (luonnon)tieteellisesti.

\section{luonto}

Käsitys luonnosta sekä luonnon ja kulttuurin dikotomia ovat määritelleet länsimaista suhdetta ei-inhimilliseen eloon ja materiaan. Raymond Williamsin (2003) mukaan luonto on käsitteistä kaikkein mutkikkain sotkuisen historiansa ja erilaisten luontokäsitysten vuoksi. Ranskan ja englannin nature juontuu latinan sanasta nascor (syntyä) (Lehtonen 2014), kun suomessa luonto on johdettu verbistä luoda. Luonto on sitä, mikä on luotu eli luomakunta. Lisäksi sillä on tarkoitettu jonkin luonnetta. (Kotimaisten kielten keskus 2020a.) Luodun ja luomakunnan myötä luonnolla on historiallinen suhde kristinuskoon, mikä on määrittänyt olennaisesti länsimaisen ihmisen asemaa suhteessa luontoon. Luonto luo jatkuvasti itseään: ollessaan ja eläessään luonnon oliot, eliöt ja ilmiöt luovat - saavat jotain aikaan (Salminen \& Vadén 2018, 25-27). Luoda-verbin alkuperäinen merkitys suomessa on ollut 'heittää' -luominen on myös luopumista, jonkin jättämistä maailmaan ja muutosta: esimerkiksi nahan luomista. (Häkkinen 2012, 74; Salminen \& Vadén 2018, 25-27.)

Länsimaisen ajattelun piirissä luonto on nähty yleensä kulttuurin ulkopuolisena rajoitteena ja ehtona. Tällaisessa käsityksessä historiallinen kehitys on ensisijaisesti vapautumista luonnon pakoista. (Ks. Haila \& Lähde 2003.) Luonnosta ja posthumanistisista näkökulmista kirjoittavat tutkijat ovat kuitenkin jo pitkään haastaneet erottelua ja nähneet luonnon ja kulttuurin lomittuvina, yhteenkietoutuneina ja sekoittuneina. Se, mitä miellämme luonnoksi, paljastuu usein tarkemmin katsottuna ihmisen muokkaamaksi. Erityisesti ympäristökriisit ovat palauttaneet luonnon kulttuurin sisäpuolelle. Timothy Morton 
(2007, 2016) on kehitellyt pimeää ekologiaa (dark ecology), jossa "pimeys" viittaa nykytilanteen kauheuden tajuamiseen: ilmastonmuutokseen, sukupuuttoihin, luonnon monimuotoisuuden hupenemiseen ja eliöyhteisöjen tuhoutumiseen. Mortonin ajattelussa ei-inhimillistä ei suljeta sosiaalisen ja kulttuurisen ulkopuolelle. Hän on myös ehdottanut, että koko luonnon käsitteestä ja ideologiasta pitäisi luopua, sillä se pitää yllä ajatusta kulttuurin ulkopuolisesta, itseään korjaavasta luonnosta. Lisäksi mm. Haraway (2003; 2008) on kehitellyt käsitteistöä, jolla kuvata kulttuurisiksi ja luonnollisiksi miellettyjen ilmiöiden sekoittumista ja yhdessä muotoutumista, kuten luontokulttuurit, kumppanuuslajit ja eläinten-kanssa-kehkeytyminen.

\section{luontokulttuuri, kumppanuuslaji}

Luontokulttuuri (natureculture) ja kumppanuuslaji (companion species) ovat Harawayn $(2003 ; 2008)$ ajattelussa keskeisiä lajienvälisiä suhteita koskevia käsitteitä. Käsitteillä on läheinen suhde toisiinsa, mutta ne operoivat eri tasoilla. Luontokulttuuri on ontologinen näkemys, joka asettuu vastustamaan tiukkaa luonnon ja kulttuurin dikotomiaa. Yhdessä elävät ihmiset ja muut lajit muodostavat toisiaan muokkaavia ja jatkuvassa muutostilassa olevia luontokulttuureita. Käsitteellä Haraway myös tarkastelee asioita, joita ei voi selkeästi asettaa kumpaankaan kategoriaan, kuten talousmetsää, domestikoituneita eläimiä, jalostettuja ruokakasveja sekä geenimuuntelua. (Haraway 2003; 2008.)

Lukuisat kulttuurin tai luonnon merkityskenttään perinteisesti ja tyypillisesti mielletyt asiat, ilmiöt ja olennot paljastuvat luontokulttuurissa kehkeytyneiksi. Esimerkiksi Heta Lähdesmäki (2015; 2020) toteaa, että villieläimiksi ja luontoon kuuluviksi koetut sudet ovat myös osa inhimillistä kulttuuria ja suomalaista yhteiskuntaa, ja kulttuuri vaikuttaa susien kehkeytymiseen sekä biologisina että kulttuurisina olentoina.

Kumppanuuslaji kuvaa lajien historiallista yhteismuotoutumista sekä erilajisten yksilöiden kehkeytymistä yhdessä jaetussa arjessa. Ihmislajin kumppanuuslajit, kuten Harawayn mielestä tärkein kumppanuuslajimme koira, ovat myös luontokulttuuria. Harawayn mukaan kumppanuuslajien yhteismuotoutuminen ja yhteinen evoluutio ovat sääntö, eivät poikkeus. Olennaista kumppanuuslajiudessa on se, etteivät kumppanuuslajit olisi sellaisia kuin ovat tai sellaisia, joiksi ovat kehkeytymässä, ilman vuorovaikutusta toisen kanssa. Ihmiset ovatkin Harawayn sanoin eläinten-kanssa-kehkeytyneitä (becoming-with-animals, suom. Ruonakoski 2015, 266). (Haraway 2003; 2008.) Näin ihmisten kumppanuuslajeja ovat yhtä lailla meille läheinen koira kuin myös susi (Lähdesmäki $2020,35)$, joka on vaikuttanut ja vaikuttaa voimakkaasti ihmisten toimintaan ja johon ihmiset vaikuttavat esimerkiksi määrittelemällä susia häirikkösusiksi ja metsästämällä niitä tietyin perustein. 
Companion species on suomennettu ainakin "kumppanuuslajiksi" (Rojola 2012), "kumppanilajiksi" (Ruonakoski 2015) ja "seuralaislajiksi" (Lummaa 2010). "Kumppanuuslaji" korostaa suhdetta - kumppanuutta - ja kehkeytymisen prosessia. "Kumppanilaji" nostaa esiin lajin, jonka kanssa ihminen on kehkeytynyt tai lajit, jotka ovat kumppanuussuhteessa. "Seuralaislaji" tuntuu kategoriana kapeammalta kuin kumppanuus: kumppanuuslajius on Harawaylle biologinen, filosofinen, materiaalis-semioottinen ja yhteiskunnallinen kategoria (Haraway 2003, 15-16) - eli paljon muutakin kuin seuraa ja seuralaisuutta. Toisaalta myös companion species tuntuu käsitteenä tavoittavan vain osan suhteesta ja kehkeytymisestä, ja käsite on myös positiivisessa latauksessaan harhaanjohtava: vaikka kumppanuuslajiuteen voi kuulua kummankin lajin kannalta positiivisia ilmiöitä, ratkaiseva tekijä ei ole positiivisuus vaan yhdessä kehkeytyminen. Esimerkiksi ihmisten ja susien vaikutus toisiinsa ei ehkä ole kumppanuutta siinä mielessä kuin kumppanuus yleensä ymmärretään (ja koirasuhteissakin on monenlaisia hankauksia ja suoranaista väkivaltaa), mutta ihmiset ja ei-inhimilliset eläimet voidaan nähdä kumppaneiksi yhteisessä jaetussa maailmassa.

\section{yhteismuotoutuminen, kehkeytyminen}

Karen Baradin ajattelussa intra-action on osa "virtausten ontologiaa", jossa maailmassa oleminen ymmärretään "jatkuvana, luovana kehkeytymisenä" (Barad 2003; Irni ym. 2014a, 31). Ontologisesti ensisijaisia eivät ole yksittäiset toimijat vaan prosessit, joissa toimijat muotoutuvat. Rinnakkaiskäsitteenä voidaan pitää käsitettä becoming (with), joka on käännetty "tulemisena", "toiseksi tulemisena" (Haapoja 2020), "keskinäisenä tulemisena" (Vehviläinen 2014, 310) tai juuri "kehkeytymisenä" (Ruonakoski 2015). Intra-action on kuitenkin kehkeytymistä monisyisempi.

Muokattu elämä -artikkelikokoelman kirjoittajat ovat päätyneet esittämään intra-action-käsitteelle kahta suomenkielistä käännöstä, jotka korostavat sen eri puolia (Irni ym. 2014b, 436-440). Ensimmäinen käännös, "sisäisvaikutus", korostaa jatkumoa alkuperäisen käsitteen sisältämään vaikutusten uudelleenajatteluun ja erityisesti käsitteellistä eroa kahden tai useamman asian keskinäiseen vuorovaikutukseen (interaction). Toinen käännös, "yhteismuotoutuminen", jättää kääntämättä Baradin ajatuksen kausaalisuudesta ja korostaa sen sijaan prosessia, jossa "erillisinä yksilöinä pidetyt olennot tai asiat muotoutuvat toisistaan erottamattomasti" (mts.). Kokoelmassa käytetään tätä jälkimmäistä käännöstä, ja se on ehkä myöhemmissäkin Baradin käsitteistöä hyödyntävissä teksteissä käytetympi (Meskus 2014, 66; vrt. esim. Radomska \& Åsberg 2020).

Yhteismuotoutuminen on jännitteisessä suhteessa kehkeytymiseen. Siinä missä kehkeytyminen (becoming) korostaa prosessia ja liikettä, yhteismuotoutuminen korostaa muotoja ja erilliseksi ja rajatuksi muotoutumista, siis morfologioita: 
muotoja ottavat ainakin organismit, käsitteet ja käytännöt. Yhteismuotoutumisen ja (keskinäisen) kehkeytymisen käsiteryppään sumeutta kuvaa se, että kaikki termit sulautuvat ajoittain toisiinsa: "Keskinäisen muotoutumisen prosessissa muokkautuu luonto, viljelylaarissa kasvatettavat kasvit sekä viljelevät ihmiset ja yhteisöt ja niiden tilanteinen tieto" (Vehviläinen 2014, 319).

\section{ihminen, inhimillinen, ei-ihminen, ei-inhimillinen}

Ihminen (man tai human) näyttäytyy posthumanistisessa ajattelussa modernin aikakauden avainkäsitteenä, joka nousi hallitsemaan länsimaisia todellisuuskäsityksiä 1600-luvulla alkaneen valistusajattelun myötä. Ihmistä tarkastellaan näin ennen kaikkea humanistisen ajatteluperinteen luomuksena, jonka avulla on perusteltu ja normalisoitu tiettyjä vallankäytön, ulossulkemisen ja sorron mekanismeja. Pyrkiessään ei-ihmiskeskeiseen tarkastelutapaan posthumanistinen tutkimusnäkökulma ei tyydy ainoastaan haastamaan humanistisia subjektikäsityksiä, vaan painottaa monensuuntaisia yhteyksiä, suhteita ja kytköksiä inhimillisen ja ei-inhimillisen välillä sekä näiden suhteiden tuotoksena syntyvien identiteettien epäyhtenäisyyttä (vrt. Braidotti 2013, 143-145).

Humanistisessa ajattelussa ihminen on totuttu tulkitsemaan yleispätevästi järjellisen ajattelun varassa toimivaksi subjektiksi, jota määrittää erityisesti kyky tietoiseen toimintaan ja harkittuihin tekoihin. Tähän perustuu myös ajatus ihmisestä luonnon yläpuolelle nousevana hahmona, joka kykenee ohjailemaan historiaa haluamaansa suuntaan. Posthumanistisessa tulkintakontekstissa tämä länsimaisen ajattelun kantava lähtökohta kyseenalaistetaan ja pyritään korvaamaan ihmiskäsityksellä, joka ei määrity vastakohtaisessa suhteessa eiinhimilliseen. Ihminen ei ole enää kaiken mitta, vaan yhdessä erilaisten materiaalisten ja teknologisten muotojen ja toimijuuksien kanssa kehittynyt hahmo, olio tai voima (Lummaa \& Rojola 2014, 14).

Ihmisen kategoria on totuttu määrittelemään lähtökohtaisesti negaation kautta: ihmistä tuotetaan erottamalla se kaikesta ei-inhimillisestä kuten eläimistä, koneista, luonnosta ja materiasta. Posthumanistisessa ajattelussa tällaiset erottautumisen, puhtauden, yhtenäisyyden ja rajaamisen diskurssit korvataan muun muassa yhteenkytkeytymiä, sekoittumia, koosteita, kontaminaatioita, takaisinkytkentöjä tai informaatioyhteyksiä painottavilla ihmiskäsityksillä (Nayar 2018, 5).

Tästä huolimatta käytännön tutkimustyö joutuu operoimaan yleisen kielenkäytön tasolla erilaisten binääristen oppositioparien tuottamien erontekojen varassa. Ihmisen ja inhimillisen vastinparina näyttäytyy näin erityisesti ei-inhimillinen (non-human tai nonhuman), joka esiintyy posthumanistisessa tutkimuksessa sekä itsenäisenä käsitteenä (ei-inhimilliset kollektiivisena joukkona) että 


\section{Jos haluamme ajatella uudella tavalla, joudumme ajattelemaan myös käsitteemme uusiksi.}

esimerkiksi luontoa, eläimiä tai materiaa koskevana määritteenä (esimerkiksi ei-inhimillinen materia).

Ihmisyyteen ja inhimillisyyteen liittyvät piilomerkitykset aiheuttavat eiinhimillisen käsitteelle omat haasteensa. Suomen kielen ihmisyyteen liittyvään sanastoon ei ole ujuttautunut yhtä sukupuolittuneita rakenteita kuin esimerkiksi englannin käsitteeseen Man, mutta "inhimillisyyteen" liittyy monenlaisia kunnioittavaan ja arvokkaaseen kohteluun liittyviä moraalisia konnotaatioita. Inhimillisyydellä viitataan siis paitsi yleisesti ihmisyyteen, myös merkityksiin, jotka tulevat lähelle lainasanan "humaani" (humane) moraalista merkityssisältöä. "Ei-inhimilliseen" uhkaakin sekoittua myös "epäinhimillisyyteen" liittyviä mielleyhtymiä. Tätä ylimenoaluetta ovat tarkastelleet esimerkiksi taiteilijat Laura Gustafsson ja Terike Haapoja teoksessaan Epäihmisyyden museo (2016-), joka ohjaa tunnistamaan, kuinka epäinhimillistämisen käytännöt ovat alistaneet sekä eläimiksi että ihmisiksi määriteltyjä (ks. myös Haapoja 2020).

"Ei-inhimilliselle" on tarjottu joitakin vaihtoehtoja erityisesti humanistisyhteiskuntatieteellisen eläintutkimuksen alalla. Ei-inhimillisten eläinten (nonhuman animals) sijaan voimme näin puhua esimerkiksi vieraslajisista, vierasmaailmaisista, tois(en)lajisista tai muunlajisista eläimistä (ks. esim. Ilomäki \& Lauhakangas 2002, 15; Lummaa 2013; Kaski 2019; Ollila 2020). Vaikka näitäkään käsitteitä ei voi pitää kaikilta osin ongelmattomina, ne säilyttävät alkukieliseen ilmaukseen kuuluvan ajatuksen ihmisistä yhtenä eläinlajina muiden joukossa ja onnistuvat välttämään ihmisen ja muun luonnon välille luodun selkeän vastakkainasettelun (käsitteiden kritiikistä ks. esim. Oksanen 2003; Tuomivaara 
2003, 11). Englannin kielessä vastakkainasetteluja on haastettu myös rinnakkaiskäsitteillä other than human ja more-than-human.

\section{ihmistä laajempi, ihmisen ylittävä}

Maailmat, kokemukset, elollinen ja eloton, luonnonvoimat ja henkiolennot levittäytyvät ihmisten ympärille. Muiden olentojen kyvyt, aistit ja historiat ylittävät ihmisten taidot ja usein myös ymmärryksen. Ihmiset ovat vaikuttuneet, vaikuttavat, tulleet omissa kehoissaan osallisiksi ja osallistetuiksi tähän eloisaan vellontaan.

Kun tutkija käyttää termiä ihmistä laajempi tai ihmisen ylittävä (more-thanhuman), hän on tekemisissä paljon käytetyn mutta vaikeasti määrittyvän termin kanssa. Termin asettumattomuus myönnetäänkin usein auliisti, mutta siitä huolimatta sen käyttö perustellaan usein juuri sen monitahoisuudella; voihan sen avulla kutsua yhdellä henkäyksellä esiin niin mineraalit, kasvit, luonnon voimat kuin henkimaailmankin, kuten Maria Puig de la Bellacasa (2017, 1) toteaa. Termi sallii elottoman ja elollisen, pienen ja suuren läsnäolon samassa ajattelemisen tilassa ilman, että näitä asioita on tarve asettaa hierarkioihin tai erotella kategorioilla. Se olettaa kaikelle yhteen tulevalle saman arvon.

Puig de la Bellacasan huomautus osoittaa kuitenkin, että termin käytöllä on myös ehtonsa: olentojen ja olemusten yhteenkietoutuneisuus ja keskinäisriippuvuus. Anna Lowenhaupt Tsing (2015) asettaa termin osoittamaan maisemaa tilana, jossa sienten, sienten kumppanikasvien ja ihmisten suhteet ovat osa maiseman historiallista prosessia. Tsingillä termi onkin sidoksissa relationaalisuuden lisäksi myös historiallisuuteen ja paikallisuuteen.

Terminä ihmistä laajempi tai ihmisen ylittävä määrittyykin oikeastaan vasta, kun sen asettaa johonkin kontekstiin. Se kutsuu usein luokseen jonkun kumppanisanan, jonka kanssa se muodostaa yhteyden. Esimerkiksi Cecily Maller (2018) ja Sarah Robertson (2018) käyttävät termiä muodossa "ihmistä laajempi kaupunki" (more-than-human city) osoittaakseen, että kaupunki on myös muiden kuin ihmisolentojen asuttama ja muovaama tila. Termi muistuttaa, että ihminen ei selviä erillään muista: ihminen ei ole toimijana mahdollinen ilman hänessä ja hänen ympärillään laajenevia olemassaolon muotoja.

Vaikka ihmistä laajempi -termiä on mahdollista kritisoida sen ihmiskeskeisyydestä, on ihmisen läsnäolo termin keskiössä myös perusteltua. Koska termi lähtee liikkeelle ihmisestä, jonka ympärillä tai sisäpuolella, vaikkapa ihmisen mikrobistossa (ks. esim. Haapoja 2011) jokin aika, tila tai verkosto laajenee, se olettaa inhimillisen toimijan, jolla on kykyä muun kuin itsensä havaitsemiseen. Termin sisällä toimii tarkkaavainen ihminen (Tsing 2015, 155-156). Termiä käytetäänkin usein kuvaamaan myös alkuperäiskansojen maailmankuvaa ja tapaa sitoutua kunnioittavasti omaan elinympäristöönsä ja siinä vaikuttaviin olentoihin (Wright 2015, 403; Larsen \& Johnson 2017). 
Termin kääntämisen kontekstuaalisuuden osoittaa hyvin se, että kutsuessaan vierelleen esimerkiksi sanan "eläin" (more-than-human animal) se kääntyy luontevammin suomeksi muotoon "ihmisen ylittävä". Ihmisen ylittävä eläin voi olla esimerkiksi koira, jonka kyvyt jossakin tilanteessa ylittävät ihmisen kyvyt (Robertson 2012, 270). Tällöin termin käyttö sisältää jälleen kehotuksen muistaa ihmisen rajallisuus: monessa suhteessa monet muut ovat omaa lajiamme taitavampia, siis antakaamme arvo sille.

\section{hoiva, vastuu, vastuunottamisen kyky}

Hoivaa (care) on käsitelty posthumanistisessa ja feministisessä uusmaterialistisessa kirjallisuudessa eettis-poliittisena käsitteenä ja toimintana. Puig de la Bellacasa (2017) kytkee hoivan teoretisointinsa vahvasti Harawayn (esim. 2016) relationaaliseen ontologiaan. Suomenkielisessä feministisessä tutkimuksessa huolenpito nousee toiseksi termiksi hoivan rinnalle (Kinnunen 2017; Koskinen ym. 2018). Ne molemmat rakentuvat keskinäisriippuvuuden varaan, mutta huolenpito-sanassa korostuu vahvemmin huoli, jopa suru huolenpidon kohteesta. "Huolenpito" on siis caren käännöksenä osittain ongelmallinen, koska se juontaa kaksimerkityksiseen sanaan huoli. Kielitoimiston sanakirjan mukaan huoli on sekä "'levoton, huolehtiva ajatus jstak, murhe; levottomuus; pelko"' että "'huolehtiminen, huolenpito, hoiva". Jälkimmäisen merkityksen mukaiseen huoleen sisältyvät 'pitää huolta' ja toisaalta myös 'kantaa huolta'. Kotimaisten kielten keskuksesta (2020b) on todettu, että "(v)anhempana merkityksenä on pidetty ensin mainittua, ja sanalla onkin ollut murteissa hyvinkin konkreettisen 'surun' merkitys. [--] 'Huolen kantaminen' tai 'huolen pitäminen' lienee alkuaan siis ollut surunmerkkien pitoa."

Jos care suomennettaisiin "huolenpidoksi", jolloin se sisältäisi myös huolen kantamisen merkityksen, se voisi avata uusia näkökulmia ekokatastrofien ja ilmastokriisin aikakaudella tehtävään tutkimukseen. "Surunmerkkien pito" suhteessa luonnon monimuotoisuuden köyhtymiseen, sulaviin jäätiköihin ja tuotantoeläinten vapauden riistoon voidaan nähdä askelena kohti kollektiivisempaa maailmankuvaa - sellaista, jossa ihminen on osa planetaarista maailmaa: ei vain sen hyödyntäjä, vaan myös takaisinantaja.

Verbi to care kääntyy suomenkielisissä teksteissä hoivaamiseksi. Hoivaaminen sisältää sitoutumisen elementin. Sitoutuminen hoivaan merkitsee sitoutumista myös "hankaliin ja ärsyttäviinkin ulottuvuuksiin, itsepintaista elinkelpoisten suhteiden ylläpitoa" (Koskinen ym. 2018, 22). Sitoutumisen kohteena näyttäytyy siis hoivan eksplisiittinen praksis, hoivaaminen, eikä hoivaamisen "objekti". Sitoutuminen ohjaa myös pohdintaan velvoittavuudesta. Relationaalisen ontologian mukaisia hoivasuhteita määrittää niihin sitoutuminen ilman pakkoa: hoivaamme, vaikka moraalisäännöstöt tai totunnaiset toimintatavat eivät meitä siihen välttämättä velvoita (mts. 19). Mutta mitä on velvoittavuus 
ja vastuu ilman moraalista velvoitetta? Haraway (2016) käsittelee vastuullisuutta response-ability -käsitteen avulla. Vastuunottamisen/vastaamisen kyky voisi suomeksi kuvata tätä eettisesti latautunutta käsitettä. Teo Ala-Ruona $(2018,45)$ käsittelee sitä "vastuullisuuden ja vastaamisen harjoitteluna", missä harjoittelu viittaa kärsivälliseen, affektiiviseen työhön, jolle joudumme omistautumaan pystyäksemme avautumaan suhteiselle hoivalle ja ihmisen ylittävälle elämälle.

Tarja Salmela ja Anu Valtonen $(2019,20)$ ovat vieneet response-abilityn käsitettä syvemmälle suhteisen olemassaolomme ontologiaan puhumalla kollektiivisen vastuunoton kyvystä (response-able-with). Käsite hahmottaa yhtäaikaisesti sitä, kuinka tunnistamme paikkamme vain yhtenä lajina maailmamme kompleksisissa suhteisuuksissa, ja sitä, kuinka otamme vastuuta tästä perustavanlaatuisesta suhteisuudesta (ks. myös Radomska 2010, 109).

\section{materia}

Uusmaterialistisessa teoriassa kaikuu englanninkielinen sanaleikki: matter matters tai matter comes to matter (ks. esim. Barad 2003; Iovino \& Oppermann 2012; Haraway 2016). Toisin kuin suomenkieliset "materia" ja "materiaalisuus", englanninkielinen matter kantaa merkityssisältöjä, jotka viittaavat fyysisen aineen lisäksi siihen, että jollain on väliä. Matter-sanalla on merkityksiä (physical matter, subject matter, to matter), jotka johtavat usein toistoon lauseen sisällä. Käännettäessä suomen kieleen sanaleikki muuttuu toteavaksi: "materia merkityksellistyy" tai "materialla on väliä". Toki materiakin voi materialisoitua tai aine aineellistua, mutta käännöksissä materia tai aine on mieluummin merkityksellistynyt.

Uusmaterialistinen lähestymistapa on siirtänyt painoa kielellisestä toiminnasta materiaalisiin dynamiikkoihin, jolloin on samalla argumentoitu, että kielellinen ja mielellinen ovat myös materiaalisia (ks. esim. Coole \& Frost 2010). Tämä on myös Harawayn materiaalis-semioottisen toinen puoli: materiaaliseen maailmaan mieltämämme asiat eivät koskaan ole vain materiaa, vaan ne käsitteellistetään merkityksellisiksi. Käsitteissä kulkee mukana esikäsitteellisiä tuntuja, "kokemuksellisia laahuksia" (Salminen \& Vadén 2018, 59): materiassa ainakin matter ja välittäminen, humanismissa humus ja ihminen. Filosofi David Abram (2010) on ehdottanut myös, että ihmisten kielten rikkaus on paljosta velkaa toisten eläinten kielille - toistamme toistemme äänteitä ristiin, lajirajoista piittaamatta, vaikuttuen ja vaikuttaen (vrt. Lummaa 2010).

Myös materian käsite esiintyy siis kielestä kieleen toisin, toisenlaisissa suhteissa ja lauseympäristöissä, käyttäen erilaista valtaa ja kutsuen esiin erilaisia kielioppeja, järjestyksiä ja rakenteita. Materia ei ole kohde, objekti tai yksikkö, joka käännetään ainoastaan käsitteenä, vaan samalla kääntyy käsittely ja käsittäminen - jotka ovat yhtä lailla materiaalisia. Olennaista on, että tämä käsitteellistämisen liike ei koskaan tule päätökseen. 


\section{Viitteet}

1 Tekijät kiittävät Aino-Kaisa Koistista, Katve-Kaisa Kontturia, Elli Saloa ja tämän numeron toimittajia kanssa-ajattelusta sanastohankkeen eri vaiheissa.
2 Suomenkielisessä käännöksessä "eläminen" ei toki ole muodoltaan gerundi vaan IV infinitiivi.

\section{Kirjallisuus}

Abram, David 2010. Becoming Animal. An Earthly Cosmology. New York: Vintage Books. https://doi. org/10.1080/14688417.2010.10589067

Agamben, Giorgio 1998. Homo Sacer. Sovereign Power and Bare Life. (Homo Sacer: Il potere sovrano e la nuda vita, 1995.) Käänt. Daniel Heller-Roazen. Stanford: Stanford University Press. https://doi. org/10.1515/9780804764025

Ala-Ruona, Teo 2018. NÄMÄ MAAILMAT OVAT JO. Kirjoittaminen queer-feministisenä maailman tekemisenä. Taideyliopiston Teatterikorkeakoulun opinnäytetyo . https://anateoalaruona.net/ wp-content/uploads/2018/12/PDF.pdf (23.1.2021).

Barad, Karen 2003. Posthumanist Performativity: Toward an Understanding of How Matter Comes to Matter. Signs: Journal of Women in Culture and Society 28(3): 801-831. https://doi. $\operatorname{org} / 10.1086 / 345321$

Braidotti, Rosi 2013. The Posthuman. Cambridge: Polity.

Braidotti, Rosi 2019. Posthuman Knowledge. Cambridge: Polity.

Coole, Diana \& Samantha Frost 2010. Introducing the New Materialisms. Teoksessa New Materialisms. Ontology, Agency, and Politics. Toim. Diana Coole \& Samantha Frost. Durham: Duke University Press, 1-43. https://doi.org/10.1215/9780822392996-001

Haapoja, Terike 2011. Kenen Show? Esitys 12(1), 10-12. Todellisuuden tutkimuskeskus. https:// todellisuus.fi/esitys-lehdet/esitys-1-2011.pdf. (23.1.2021).

Haapoja, Terike 2020. Miten olla ihmisiksi? Teoksessa Nuppukirja. Maallisen elämän käsikirja. Toim. Laura Gustafsson \& Terike Haapoja. HAM Helsingin taidemuseon julkaisu 145. Helsinki: Helsingin taidemuseo, 8-18.

Haila, Yrjö \& Ville Lähde 2003. Luonnon poliittisuus: Mikä on uutta? Teoksessa Luonnon politiikka. Toim. Yrjö Haila \& Ville Lähde. Tampere: Vastapaino, 7-36.

Haraway, Donna 1997. Modest Witness@Second_Millenium.FemaleMan@_Meets_On coMouse ${ }^{\text {TM }}$ :Feminism and Technoscience. New York: Routledge.

Haraway, Donna 2003. Companion Species Manifesto. Dogs, People, and Significant Otherness. Chicago: Prickly Paradigm Press.

Haraway, Donna 2008. When Species Meet. Minneapolis: University of Minnesota Press.

Haraway, Donna 2016. Staying with the Trouble. Making Kin in the Chthulucene. Durham: Duke University Press. https://doi.org/10.1515/9780822373780

Häkkinen, Kaisa 2012. Kielitiede. Teoksessa Monitieteinen ympäristötutkimus. Toim. Karoliina Lummaa, Mia Rönkä \& Timo Vuorisalo. Helsinki: Gaudeamus, 73-76.

Ilomäki, Henni \& Outi Lauhakangas 2002. Lukijalle. Teoksessa Eläin ihmisen mielenmaisemassa. Toim. Henni Ilomäki \& Outi Lauhakangas. Helsinki: Suomalaisen Kirjallisuuden Seura, 7-25.

Iovino, Serenella \& Serpil Oppermann 2012. Material Ecocriticism: Materiality, Agency, and Models of Narrativity.Ecozon@3(1),75-91. https://doi.org/10.37536/ECOZONA.2012.3.1.452 
Irni, Sari, Mianna Meskus \& Venla Oikkonen 2014a. Teknotieteen, sukupuolen ja materiaalisuuden muunnelmat. Teoksessa Muokattu elämä. Teknotiede, sukupuoli ja materiaalisuus. Toim. Sari Irni, Mianna Meskus \& Venla Oikkonen. Tampere: Vastapaino, 7-48.

Irni, Sari, Mianna Meskus \& Venla Oikkonen 2014b. Epilogi: käsitteiden kääntämisestä. Teoksessa Muokattu elämä. Teknotiede, sukupuoli ja materiaalisuus. Toim. Sari Irni, Mianna Meskus \& Venla Oikkonen. Tampere: Vastapaino, 436-447.

Jackson, Zakiyyah Iman 2013. Animal: New Directions in the Theorization of Race and Posthumanism. Feminist Studies 39(3), 669-685.

Johnson, Jay T. \& Soren C. Larsen 2017. Being Together in Place. Indigenous Coexistence in a More Than Human World. Minneapolis: University of Minnesota Press.

Kaski, Liisa 2019. Myyttiset eläimet. Tarua ja totta eläinten mahdista. Helsinki: Suomalaisen Kirjallisuuden Seura.

Kinnunen, Veera 2017. Tavarat tiellä. Sosiologinen tutkimus esinesuhteista muutossa. Acta Universitatis Lapponiensis 362. Rovaniemi: Lapin yliopisto.

Koistinen, Aino-Kaisa \& Sanna Karkulehto 2018. Posthuman(ist) Feminism, Feminist Posthumanities. Critical Posthumanism. Cenealogy of the Posthuman http://criticalposthumanism.net/ genealogy/feminism/ (14.10.2020).

Koskinen, Outi, Malla Mattila, Nina Mesiranta \& Elina Närvänen 2018. Hoiva ruokahävikin vähentämisen arkisissa käytännöissä. Alue \& Ympäristö 47 (2), 17-31. https://doi.org/10.30663/ ay. 72986

Kotimaisten kielten keskus 2020a. Luonne ja luonto. https://www.kotus.fi/nyt/kysymyksia_ja_vastauksia/sanojen_alkuperasta/luonne_ja_luonto (24.8.2020).

Kotimaisten kielten keskus 2020b. Vastaus kysymykseen: Miksi sanalle huoli tai huolehtia on syntynyt kaksi eri merkitystä, melkein vastakkaiset? https://www.kirjastot.fi/kysy/miksi-sanallehuoli-tai-huolehtia (26.8.2020).

Lehtonen, Mikko 2014. Maa-ilma. Materialistisen kulttuuriteorian lähtökohtia. Tampere: Vastapaino.

Lummaa, Karoliina 2010. Poliittinen siivekäs. Lintujen konkreettisuus suomalaisessa 1970-luvun ympäristörunoudessa. Jyväskylä: Nykykulttuuri.

Lummaa, Karoliina 2013. Vieraslajisuudesta vierasmaailmaisuuteen -lintujen kohtaamisen uutta runousoppia. Kirjallisuudentutkimuksen aikakauslehti Avain 2/2013, 25-42.

Lummaa, Karoliina \& Lea Rojola 2014. Johdanto: Mitä posthumanismi on? Teoksessa Posthumanismi. Toim. Karoliina Lummaa \& Lea Rojola. Turku: Eetos, 13-32.

Lähdesmäki, Heta 2015. Susi yhteiskunnallisena eläimenä. Teoksessa Eläimet yhteiskunnassa. Toim. Elisa Aaltola \& Sami Keto. Helsinki: Into, 185-191.

Lähdesmäki, Heta 2020. Susien paikat. Ihminen ja susi 1900-luvun Suomessa. Jyväskylä: Nykykulttuuri. https://doi.org/10.23984/fjhas.90162

Maller, Cecily 2018. Healthy Urban Environments. More-Than-Human Theories. Milton: Routledge. https://doi.org/10.4324/9781315620534

Mbembe, Achille 2003. Necropolitics. Public Culture 15(1), 11-40. https://doi. org/10.1215/08992363-15-1-11

Meskus, Mianna 2014. Hedelmöityshoidot ruumiillisena kokemuksena. Teoksessa Muokattu elämä. Teknotiede, sukupuoli ja materiaalisuus. Toim. Sari Irni, Mianna Meskus \& Venla Oikkonen. Tampere: Vastapaino, 51-85.

Morton, Timothy 2007. Ecology without Nature. Rethinking Environmental Aesthetics. Cambridge, MA: Harvard University Press.

Morton, Timothy 2016. Dark Ecology. For a Logic of Future Coexistence. New York: Columbia University Press. https://doi.org/10.7312/mort17752

Nayar, Pramod K. 2018. Posthumanism. Cambridge: Polity. 
Oksanen, Markku 2003. Humanistista eläintutkimusta. Agricola: Suomen humanistiverkko. https:// agricolaverkko.fi/review/humanistista-elaintutkimusta/ (4.9.2020).

Ollila, Tiina 2020. Muunlajisia oomme kaikki, kaikki! Eläimiksi. Kriittisen eläintutkimuksen näkökulmia. http://www.elaimiksi.fi/2020/02/21/tiina-ollila-muunlajisia-oomme-kaikki-kaikki/ (14.10.2020).

Puig de la Bellacasa, Maria 2017. Matters ofCare. Speculative Ethics in More than Human Worlds. Minnesota: University of Minnesota Press.

Pulkkinen, Tuija 2003. Valtio. Teoksessa Käsitteet liikkeessä. Toim. Matti Hyvärinen, Jussi Kurunmäki Kari Palonen, Tuija Pulkkinen \& Henrik Stenius. Tampere: Vastapaino, 213-255.

Radomska, Marietta 2010. Towards a Posthuman Collective: Ontology, Epistemology and Ethics. Praktyka Teoretyczna 1/2010, 93-115. https://doi.org/10.14746/prt.2010.1.7

Radomska, Marietta \& Cecilia Åsberg 2020. Elämästä luopuminen. Biofilosofiasta, epä/elämisestä, toksisesta ruumiillistumisesta ja etiikan uudelleenmuotoilusta. Niin \& näin 1/2020, 39-56.

Raipola, Juha 2014. Inhimilliset ja postinhimilliset tulevaisuudet. Teoksessa Posthumanismi. Toim. Karoliina Lummaa \& Lea Rojola. Turku: Eetos, 35-56.

Robertson, Chris 2012. Dangerous Margins: Recovering the Stem Cells of the Psyche. Teoksessa Vital Signs. Psychological Responses to Ecological Crisis. Toim. Mary-Jayne Rust \& Nick Totton. Taylor \& Francis Croup. ProQuest Ebook Central, https://ebookcentral-proquest-com.libproxy.helsinki. fi/lib/helsinki-ebooks/detail.action?docl D=822353 (23.1.2021).

Robertson, Sarah A. 2018. Rethinking Relational Ideas of Place in More-Than-Human Cities. Ceography compass 12(4), e12367-n/a. https://doi.org/10.1111/gec3.12367

Rojola, Lea 2012. Juokse lujaa, pure kovaa! Donna Harawayn kumppanuuslajit ja feminismi. Teoksessa Erotja etiikka feministisessä tutkimuksessa. Toim. Kirsti Lempiäinen, Taru Leppänen \& Susanna Paasonen. Turku: Utukirjat, 256-277.

Ruonakoski, Erika 2015. Kiintymyksen lähteillä - koira ja ihminen matkalla tulevaan. Teoksessa Eläimet yhteiskunnassa. Toim. Elisa Aaltola \& Sami Keto. Helsinki: Into, 261-283.

Salmela, Tarja \& Anu Valtonen 2019. Towards Collective Ways of Knowing in the Anthropocene: Walking-with Multiple Others. Matkailututkimus 15(2), 18-32. https://doi.org/10.33351/mt.88267

Salminen, Antti \& Tere Vadén 2018. Elo ja anergia. Tampere: Niin \& näin.

Thacker, Eugene 2015. Starry Speculative Corpse: Horror of Philosophy. Vol. 2. Winchester: Zero Books.

Tsing, Anna Lowenhaupt 2015. The Mushroom at the End of the World. On the Possibility of Life in Capitalist Ruins. Princeton: Princeton University Press. https://doi.org/10.1515/9781400873548

Tuomivaara, Salla 2003. Eläimet muuttuvassa yhteiskunnassa. Johdatus ihmisten ja eläinten välisten suhteiden sosiologiaan. Pro gradu -tutkielma. Tampereen yliopisto: Sosiologian ja sosiaalipsykologian laitos.

Vehviläinen, Marja 2014. Syömisen politiikka arjessa. Teoksessa Muokattu elämä. Teknotiede, sukupuoli ja materiaalisuus. Toim. Sari Irni, Mianna Meskus \& Venla Oikkonen. Tampere: Vastapaino, 305-341.

Viveiros de Castro, Eduardo 2019. Kannibaalimetafysiikka. Aineksia poststrukturalistiseen antropologiaan. Suom. Eetu Virén. Helsinki: Tutkijaliitto.

Williams, Raymond 2003. Luontokäsitykset. (Ideas of Nature, 1980). Suom. Mikko Lehtonen. Teoksessa Luonnon politiikka. Toim. Yrjö Haila \& Ville Lähde. Tampere: Vastapaino, 40-66.

Wright, Sarah 2015. More-Than-Human, Emergent Belongings: A Weak Theory Approach. Progress in Human Ceography 39(4), 391-411. https://doi.org/10.1177/0309132514537132 